\title{
Limnological variations of a deep reservoir in periods with distinct rainfall patterns
}

\author{
Variações na limnologia de um reservatório profundo \\ em períodos com diferentes padróes de precipitação
}

Ana Maria Geraldes ${ }^{1}$ and Catherine George ${ }^{2}$

${ }^{1}$ Centro de Investigação da Montanha - CIMO, Escola Superior Agrária - ESA, Instituto Politécnico de Bragança, Campus de Santa Apolónia, Apartado 1172, 5301-855 Bragança, Portugal e-mail: geraldes@ipb.pt

${ }^{2}$ Université Paul Verlaine, Boulevard Delestraint, 57070 Metz, France e-mail: kit-y-cat@hotmail.fr

\begin{abstract}
Aim: This study intends to provide information on how precipitation variation may impact environmental parameters (total phosphorus, water temperature, $\mathrm{pH}$, conductivity, dissolved oxygen, Secchi depth, chlorophyll $a$ and Anabaena abundance) and crustacean zooplankton composition and abundance. Methods: Samples were collected monthly from October 2000 to September 2002 and from October 2007 to September 2009 at one single sampling station located at the deepest point of the reservoir. All data were obtained in the euphotic zone. Results: The highest values of total phosphorous concentrations were reported together with the maximal values of precipitation. Conversely, conductivity decreased during the wet periods. Anabaena presence was only detected between September and December 2001. Daphnia longispina total abundance showed large inter-annual differences. A clear seasonal pattern was inferred for Diaphanosoma brachyurum and Ceriodaphnia pulchella. Both species are thermophilic and begin to be detected in early summer when the water temperature is around $15{ }^{\circ} \mathrm{C}$. Copidodiaptomus numidicus abundance did not present a clear seasonal pattern. Conclusions: Some of the observed shifts in environmental parameters (Conductivity, total phosphorus concentrations and Anabaena abundance) resulting in changes in zooplankton abundance are induced by rainfall variation. The most affected species were those with a lack of seasonality (C. numidicus) or species occurring mainly in winter/early summer (Daphnia longispina). However, a wide range of physical, chemical and biotic interactions is likely to influence zooplankton abundance. Therefore, caution is advised when relating the observed variation exclusively with rainfall intensity. In fact, some of the observed shifts were induced by other factors varying subtly in a seasonal or inter-annual pattern, independently of rainfall intensity.
\end{abstract}

Keywords: rainfall, wet and dry periods, deep reservoir limnology, crustacean zooplankton assemblage, Anabaena flos-aquae.

Resumo: Objectivo: Com o presente estudo pretende-se obter informação sobre os impactos da variação da precipitação nas concentraçôes de fósforo total, de clorofila a, oxigénio dissolvido, condutividade e profundidade do disco de Secchi, bem como na abundância de Anabaena flos-aquae e das espécies mais abundantes de crustáceos zooplactónicos. Métodos: As amostragens foram realizadas mensalmente de Outubro de 2000 a Setembro de 2002 e de Outubro de 2007 a Setembro de 2009 num único ponto localizado na zona mais profunda do reservatório. Todos os dados foram obtidos na zona eufótica. Resultados: As concentraçóes de fósforo total foram mais elevadas durante os períodos de maior precipitação. Por seu turno, a condutividade decresceu durante os períodos mencionados. Anabaena só foi detetada entre Setembro e Dezembro de 2001. A abundância de Daphnia longispina sofreu grandes variaçóes durante o decurso deste estudo. Diaphanosoma brachyurum e Ceriodaphnia pulchella apresentaram sempre um forte padrão sazonal. Ambas as espécies são termófilas e só começam a ser detetadas a partir do início do veráo quando a temperatura da água atinge os $15^{\circ} \mathrm{C}$. Copidodiaptomus numidicus não apresenta qualquer padrão sazonal. Conclusóes: Algumas das mudanças observadas nos parâmetros ambientais (condutividade, concentraçóes de fósforo total e na abundância de Anabaena) são induzidas pelas variaçóes na precipitação. Estas mudanças afetam a abundância do zooplâncton. As espécies mais afetadas são aquelas que não apresentam padróes sazonais (C. numidicus) ou espécies que ocorrem essencialmente entre o inverno e o início do verão. No entanto, uma grande variedade de interaçóes de natureza física, química e biótica são suscetíveis de afetar a abundância do zooplâncton. Assim, é 
necessário ter cautela quando se relacionam as alteraçôes na comunidade zooplanctónica exclusivamente com variaçóes na precipitação. De facto, muitas das alteraçóes observadas são induzidas por outros fatores que variam de forma subtil sazonalmente ou interanualmente e independentemente da intensidade da precipitação.

Palavras-chave: precipitação, períodos chuvosos e secos, limnologia de reservatórios profundos, comunidade de crustáceos zooplactónicos, Anabaena flos-aquae.

\section{Introduction}

In regions where water is a limiting factor, most of the rainfall is concentrated in a single period. Besides, both the intensity and quantity of rainfall vary markedly from one year to another. Precipitation variability can generate different kinds of seasonal patterns, modifying water turnover time and changing the intensity of environmental processes. An example is the increase of the external loading of nutrients, organic matter and pollutants linked to intense rainfall events (Armengol et al., 1994, 1999; Catalan and Fee, 1994; Soria et al., 2000; Wetzel, 2001; Marcé et al., 2006; Jones et al., 2008). Consequently, zooplankton is constantly exposed to a great variation of environmental factors, whose fluctuations constrain the size, reproduction and survival of populations. Because of its quick response to environmental change, zooplankton can be regarded as an indicator of disturbance events (Lampert and Sommer, 1997; Jeppesen et al., 1999; Pereira et al., 2002; Abrantes et al., 2009; Obertegger et al., 2010). Therefore, zooplankton can be directly or indirectly influenced by precipitation events. Understanding how precipitation influences the magnitude of the interactions between environment and zooplankton is an important source of information about reservoir behaviour.

An unprecedented project with the aim of obtaining long term limnological data was put into practice in 2000 in Azibo Reservoir (NE Portugal). This reservoir was chosen because unlike the majority of existing reservoirs, where water level fluctuates more than $10 \mathrm{~m}$ over the annual cycle, here, human-caused water level fluctuations are not very pronounced, never exceeding $3 \mathrm{~m}$. Furthermore, the introduction of pike (Esox lucius L.) in the 1990's led to a marked reduction of cyprinid fish abundance. Consequently, fish predatory pressure is regarded to be too low to drive crustacean zooplankton assemblage (Geraldes and Boavida, 2004a). Without the interference of internal disturbances generated by extreme anthropogenic water level fluctuations and by fish predation, this reservoir provides a good environment for studying the potential effects of climate variation (precipitation, temperature), on environmental parameters (nutrient and phytoplankton availability), on zooplankton assemblage and ultimately on general reservoir limnology, filling the long term lack of data on this kind of aquatic ecosystems. Differences in precipitation regimes have been recorded in Portugal with values above average in the hydrological year $2000 / 2001$, normal/regular values in 2001/2002 and below average in 2007/2008 and 2008/2009. Therefore, it was hypothesized that inter-annual variations in environmental parameters (total phosphorus, water temperature, $\mathrm{pH}$, conductivity, dissolved oxygen, Secchi depth, chlorophyll $a$ and Anabaena abundance) will be directly induced by different precipitation regimes, which may also drive crustacean zooplankton composition and abundance.

\section{Material and Methods}

\subsection{Study area}

Azibo is a deep meso-eutrophic reservoir located in the Portuguese part of Douro River drainage basin (Latitude: 41 $32^{\prime} 50^{\prime \prime} \mathrm{N}$ and Longitude: $6^{\circ} 53^{\prime} 28^{\prime \prime} \mathrm{W}$; altitude: $624 \mathrm{~m}$ ). The area of the reservoir is 410 ha, with a total capacity of 54,470 $\times 10^{3} \mathrm{~m}^{3}$. The maximum and mean depths are $30 \mathrm{~m}$ and $13 \mathrm{~m}$, respectively. The mean water residence time is 2.2 years. This reservoir was first filled in 1982, thereafter being mainly used for recreation purposes. Other uses include urban water supply and irrigation, although these are not significant. The water level fluctuations vary between 1.5 and $3.0 \mathrm{~m}$ in summer. In Azibo the direct influence of human activities is higher during the summer, when the reservoir and its surroundings are used for recreation (swimming, camping, boating, angling). Activities that take place throughout the year in the drainage basin include farming and grazing (mainly sheep). The potential nutrient loads generated by these activities are $243,275 \mathrm{~kg}$ of nitrogen $(\mathrm{N})$ and $116,956 \mathrm{~kg}$ of phosphorus (P) per year (Geraldes and Boavida, 2003). Thermal stratification of the reservoir always occurs between June-October. 
Most precipitation events occur between October and March in a very irregular pattern from one year to another (Figure 1). In the region, total annual precipitation varies between 800 and $1000 \mathrm{~mm}$, and in a "normal" autumn/winter season total precipitation is around $500 \mathrm{~mm}$. (Portuguese Meteorology Institute, 2009). Further information concerning the reservoir and its surroundings can be found in Geraldes and Boavida (2003).

\subsection{Field sampling and laboratory analysis}

Samples were collected monthly from October 2000 to September 2002 and from October 2007 to September 2009 at one single sampling station located at the deepest point of the reservoir. All data were obtained in the euphotic zone. The depth of this zone was considered to be 2.5 times the Secchi disc depth. Water temperature, $\mathrm{pH}$, conductivity and dissolved oxygen (DO) were measured "in situ” using a multiparameter probe (YSI 6820). Integrated water samples were obtained at $2 \mathrm{~m}$ intervals along the euphotic zone with a Van Dorn bottle. Samples were pooled together and the total sample was used for total phosphorous (TP) and chlorophyll $a(\mathrm{Chl} a)$ determination and phytoplankton analysis.

Phytoplankton samples were fixed "in situ" with Lugol's solution. Only Anabaena flos-aquae Brébisson abundance was analysed, because the dominance of this cyanobacterium in phytoplankton assemblage is often an indicator of environmental stress. Zooplankton was collected on each sampling date by taking two vertical hauls using a $64 \mu \mathrm{m}$ mesh size Wisconsin type net equipped with a flowmeter. Animals were anaesthetised with carbonated water and preserved in sugar-saturated formaldehyde ( $4 \%$ final concentration). In Azibo the most representative zooplankton taxa are Cladocera and Copepoda. Among these, only the cladocerans Daphnia longispina (Müller, 1776) Ceriodaphnia pulchella Sars, 1862 Bosmina longirostris (Müller, 1776) and Diaphanosoma brachyurum Liévin (1848) and the copepods Copidodiaptomus numidicus (Gurney 1909), Acanthocyclops robustus Sars (1863) and their nauplii are very abundant and therefore, taken into account in this study. Sampling and laboratory procedures are fully described in Geraldes and Boavida (2003, 2004b). Monthly precipitation values were measured at the nearest town, Bragança, and obtained from the Portuguese Meteorology Institute (2009).

\subsection{Data analysis}

A Discriminant Canonical Analysis (DA) with a forward stepwise method of statistical significance was used for detecting the environmental parameters (water temperature, $\mathrm{pH}$, conductivity, DO, TP, Chl $a$ and Anabaena abundance) allowing discrimination between different hydrological years. The Partial Wilks' Lambda was used to determine what variables contribute most and least to the overall discrimination (Legendre and Legendre, 1998). To test for differences in crustacean zooplankton assemblage composition between hydrological years, a Canonical Analysis of Principal Coordinates (CAP) was performed (Anderson and Willis, 2003). To understand how much of the dissimilarity is driven by compositional and species abundance differences, a test for homogeneity of multivariate dispersions was carried out (Anderson et al., 2006).

\section{Results}

\subsection{Precipitation patterns and environmental parameters}

During the study period, precipitation varied irregularly from one hydrological year to another (from October to September) (Figure 1). In 2000/2001, precipitation levels were far above average from October to March causing intense

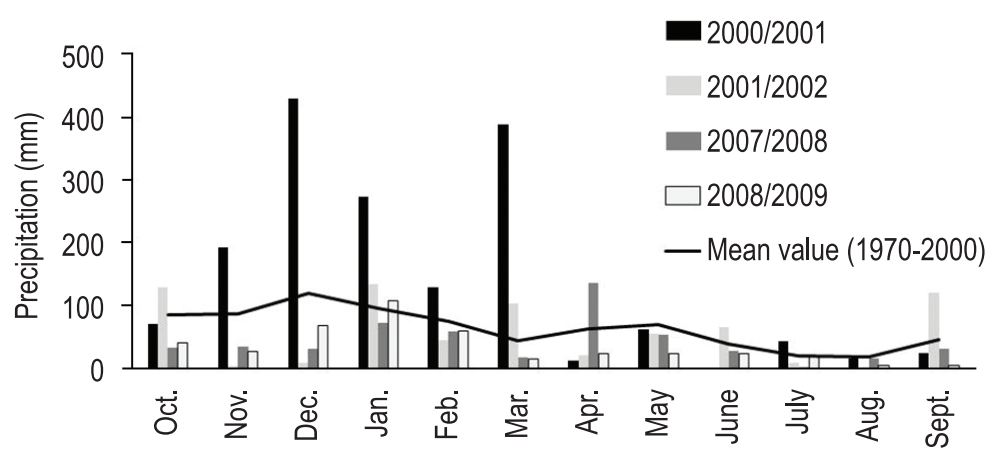

Figure 1. Monthly precipitation noticed for hydrological years of 2000/2001, 2001/2002, 2007/2008 and 2008/2009 in the town of Bragança (Portugal) (Portuguese Meteorology Institute, 2009). 
runoff events. The total precipitation recorded during this year reached $1640 \mathrm{~mm}$. Conversely, in 2001/2002 total annual precipitation was around $700 \mathrm{~mm}$. Therefore, this particular year can be considered as normal regarding precipitation levels. In 2007/2008 and 2008/2009 the total annual precipitation reported was around 509 and $414 \mathrm{~mm}$, respectively. Therefore, those periods can be regarded as dry years.

TP concentrations ranged between 20.00 (September 2008, February, April, May and June 2009) and $113.22 \mu \mathrm{g} \mathrm{L}^{-1}$ (January 2000). The highest values of TP were reported together with the maximal values of precipitation. Therefore, mean TP concentrations were higher in 2000/2001 and 2001/2002 (wet years) showing an important decrease in 2007/2008 and in 2008/2009 (dry
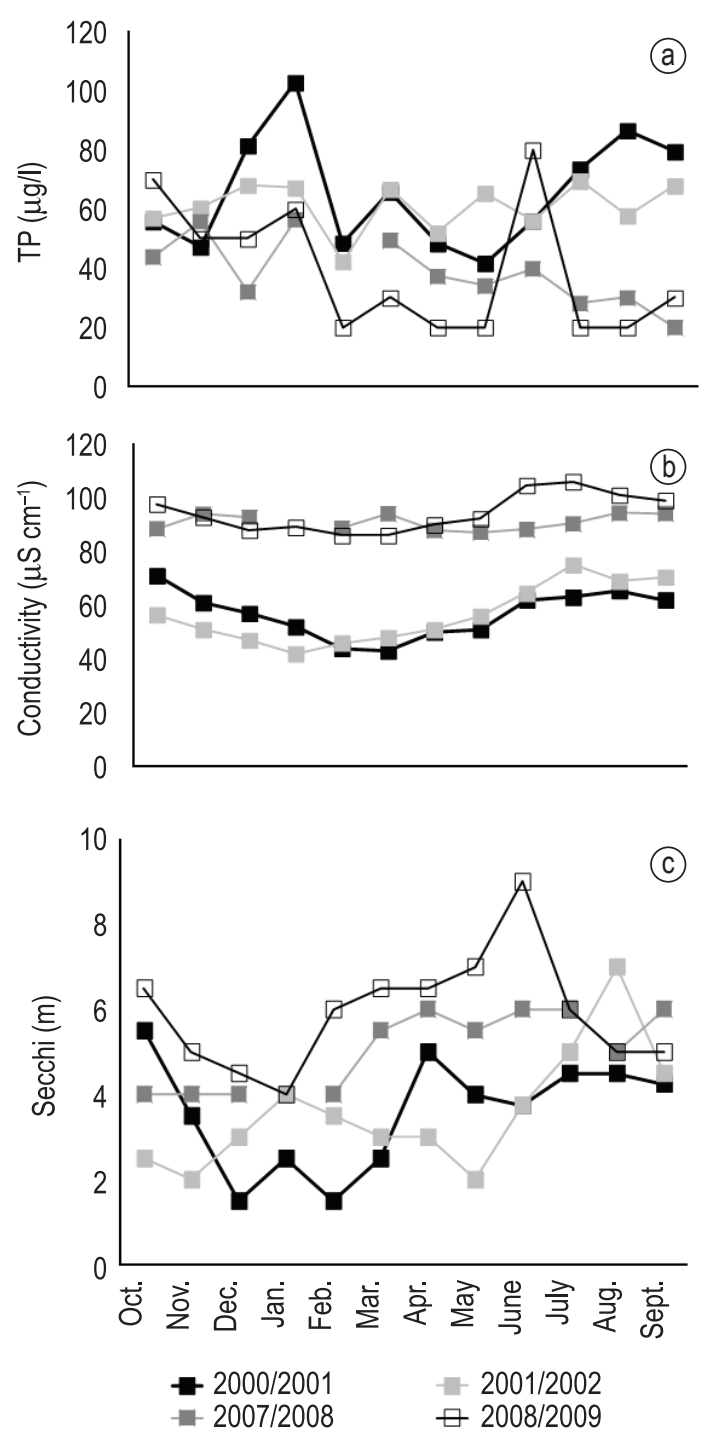

years) (Figure 2a). In 2000/2001 and 2001/2002 conductivity values reached similar values ranging between 42 and $75 \mu \mathrm{S} / \mathrm{cm}$. Conversely, during both dry years the values of this parameter increased, varying between 70 and $106 \mu \mathrm{S} / \mathrm{cm}$ (Figure $2 \mathrm{~b}$ ). Secchi depth values only decreased in December 2000 - March 2000 (a period of intense precipitation) and in September-December 2001 (a period coincident with the presence of Anabaena) (Figure 2c). Despite water temperature having always presented a similar pattern, it should be stressed that the highest winter temperatures occurred in 2000/2001 (from December 2000 to March 2001) and $2007 / 2008$ presented the lowest summer temperatures (Figure 2d). DA allowed differentiating two groups: one formed by samples obtained in 2000/2001 and 2001/2002
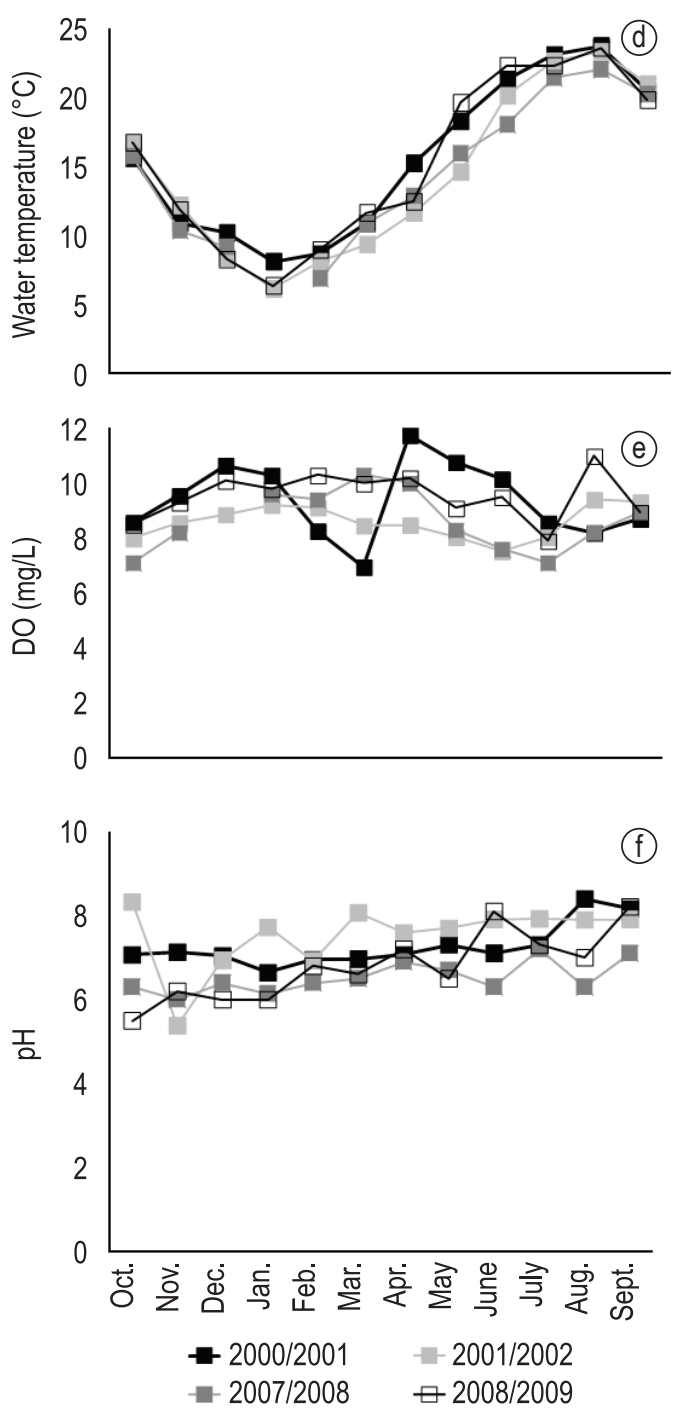

Figure 2. Monthly variation in water TP (a), conductivity (b), water transparency (c), water temperature (d), DO (e) and $\mathrm{pH}(\mathrm{f})$ in Azibo Reservoir. 
and another one consisting of 2007/2008 and 2008/2009 samples (Figure 3). Overall, the discrimination between two groups was clear. Partial Wilks' Lambda results indicated that the variables contributing most to the overall discrimination were conductivity, temperature, TP, $\mathrm{pH}$ and Anabaena abundance (Table 1).

\subsection{Anabaena abundance}

This cyanobacterium dominated phytoplankton assemblage during a very dry period, from October to December 2001 (Figure 4). This period occurred subsequently to a very wet winter $(2000 / 2001)$ (Figure 1). During this period Anabaena abundance varied between 100,000 and 250,000 ind $\mathrm{L}^{-1}$. From February 2002 onwards Anabaena was not detected.

\subsection{Crustacean zooplankton assemblage}

Daphnia longispina total abundance varied annually. In spite of the large fluctuations observed, it is possible to verify the existence of a peak in April $2000\left(10,000 \mathrm{ind} / \mathrm{m}^{3}\right)$ and $2008\left(6,000 \mathrm{ind} / \mathrm{m}^{3}\right)$. In fact, Daphnia abundance showed a similar pattern in $2000 / 2001$ and in 2007/2008. During 2001/2002
Daphnia was always present in very low densities. In 2008/2009 the highest abundance was recorded, in the winter $2008 / 2009$, more precisely in January $2009\left(7,500 \mathrm{ind} / \mathrm{m}^{3}\right)$ (Figure 5a). A clear seasonal pattern was inferred for Ceriodaphnia pulchella and Diaphanosoma brachyurum (Figure 5b, c). Both species are thermophilic and begin to be detected in early summer when the water temperature is around $15^{\circ} \mathrm{C}$. However, Diaphanosoma showed a large peak in September 2009 (5,000 ind $\left./ \mathrm{m}^{3}\right)$. Bosmina longirostris and Copidodiaptomus numidicus abundances did not present a clear seasonal pattern. Large variations on the abundance of these species from one year to another were observed (Figure 5d, e). In fact, in 2000/2001 C. numidicus became more abundant only in early spring, showing a peak in June $\left(8,000 \mathrm{ind} / \mathrm{m}^{3}\right)$ and crashing afterwards. This event was coincident with Anabaena presence. In 2001/2002 densities only increased after February and remained at the maximum until September $\left(6,000 \mathrm{ind} / \mathrm{m}^{3}\right)$. In 2008/2009 two peaks were recorded: one in February $2009\left(8,500 \mathrm{ind} / \mathrm{m}^{3}\right)$ and the other in June $2009\left(6,000 \mathrm{ind} / \mathrm{m}^{3}\right)$. Acanthocyclops robustus

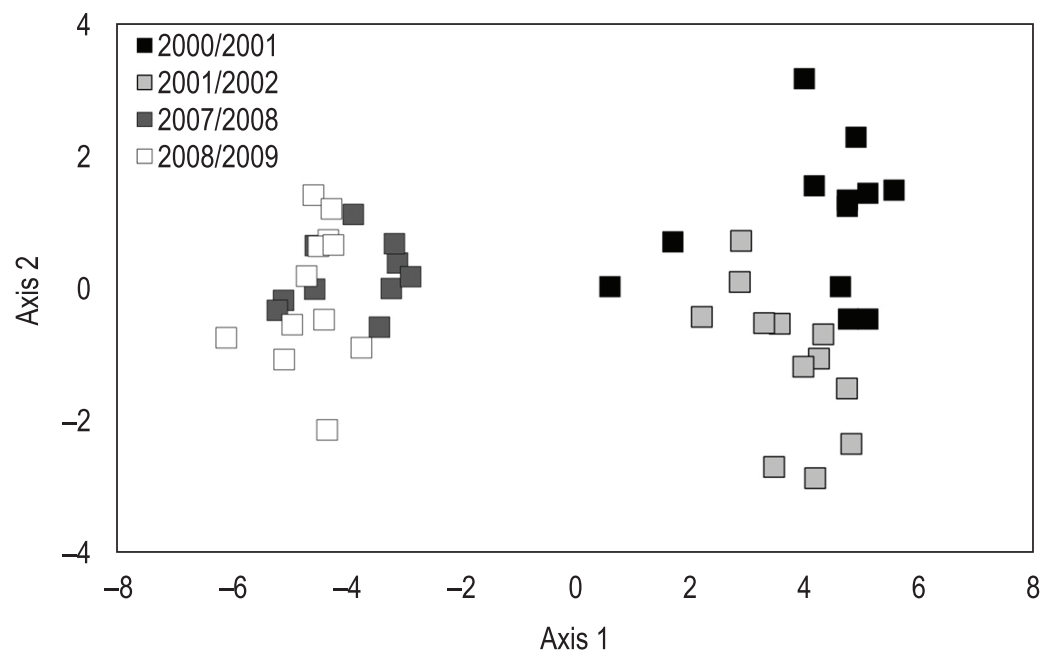

Figure 3. Discriminant analysis of environmental data. Complementary information is depicted in Table 1.

Table 1. Environmental parameters included in Discriminant Canonical Analysis with Pearson's Correlation coefficients and partial Wilks' $\lambda$ tests results.

\begin{tabular}{lccccccccccc}
\hline Variables & TP & Temp. & Cond. & pH & DO & Chl a & Secchi & Anabaena & Partial Wilks' $\lambda$ & F & P \\
\hline TP & 1.00 & -0.14 & 0.14 & -0.06 & -0.07 & 0.27 & -0.06 & 0.02 & 0.71 & 4.81 & 0.0066 \\
Temp. & -0.14 & 1.00 & 0.75 & 0.52 & -0.27 & -0.16 & 0.57 & -0.17 & 0.53 & 10.31 & 0.0001 \\
Cond. & 0.14 & 0.75 & 1.00 & 0.40 & -0.18 & -0.09 & 0.49 & -0.24 & 0.18 & 51.95 & 0.0000 \\
pH & -0.06 & 0.52 & 0.40 & 1.00 & -0.13 & -0.18 & 0.38 & -0.50 & 0.77 & 3.57 & 0.0236 \\
DO & -0.07 & -0.27 & -0.18 & -0.13 & 1.00 & -0.18 & 0.10 & 0.04 & 0.80 & 2.92 & 0.0477 \\
Chl a & 0.27 & -0.16 & -0.09 & -0.18 & -0.18 & 1.00 & -0.02 & 0.17 & 0.96 & 0.53 & 0.6653 \\
Secchi & -0.06 & 0.57 & 0.49 & 0.38 & 0.10 & -0.02 & 1.00 & -0.23 & 0.95 & 0.56 & 0.6457 \\
Anabaena & 0.02 & -0.17 & -0.24 & -0.50 & 0.04 & 0.17 & -0.23 & 1.00 & 0.78 & 3.34 & 0.0300 \\
\hline
\end{tabular}




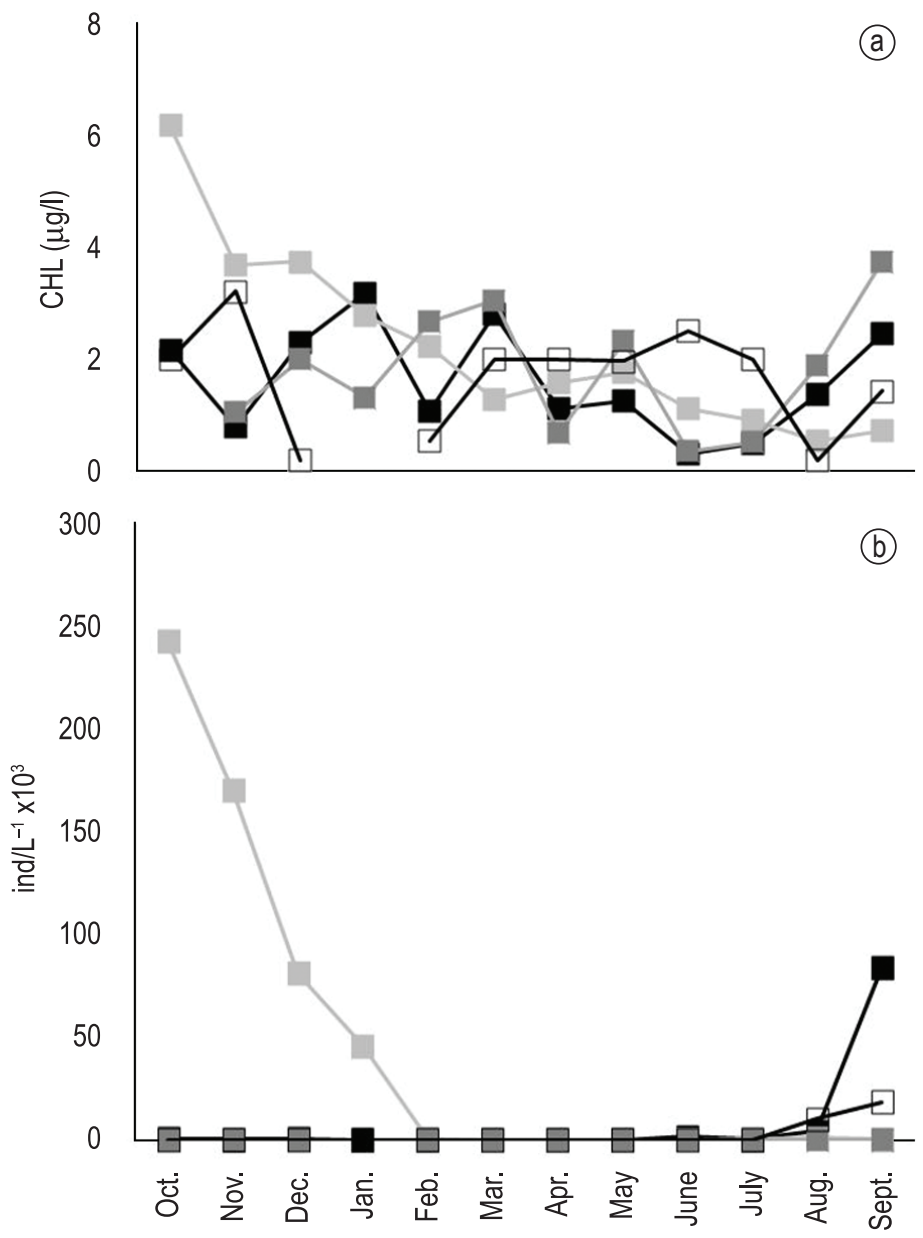

Figure 4. Chlorophyll a concentrations (a) and Anabaena densities (b) in Azibo Reservoir.

and nauplii were detected and did not show a clear seasonal or annual pattern (Figure 5f, g). CAP results indicated significant difference in the composition and relative abundance of species in the different years (Figure 6). Results of tests for homogeneity of multivariate dispersions indicated that there were significant differences in dispersion among the four years $(\mathrm{F}=9.23 ; \mathrm{P}<0.0001)$. Pairwise comparisons also revealed significant differences in species abundance and composition between 2000/2001 and 2001/2002, 2008/2009; 2001/2002, between 2007/2008 and 2008/2009 and finally between $2007 / 2008$ and 2008/2009.

\section{Discussion}

Conductivity and TP concentrations (two variables contributing more to the overall discrimination between years) seem to be directly influenced by rainfall intensity. Water inflow during wet periods increases ions dilution, which decreases conductivity. Conversely, nutrients and organic matter increase during these periods. Similar results were obtained by several authors in reservoirs located in regions influenced by Mediterranean climate (Armengol et al., 1999; Soria et al., 2000; AlvarezCobelas et al., 2006; Marcé et al., 2006; NaselliFlores, 2011). Nutrient inputs changed from one year to another as a function of rain quantity and intensity. Indeed, in 2007/2008 and in 2008/2009 precipitation values were below the mean and TP concentrations did not increase significantly and were substantially lower than those observed in 2000/2001 and 2001/2002. Despite the lack of data concerning the intensity of those processes in Azibo reservoir, it is plausible that those changes are the result of the balance between the sedimentation rates, nutrient loads and biotic recycling processes (Boström et al., 1988; Catalan and Fee, 1994; Barbosa and Hvitved-Jacobsen, 1999; Rybak, 2000). It should be stressed that Azibo's tributaries are temporary streams and they were almost dried during 2007/2008 and 2008/2009. However, in wet years those tributaries can be an important source of nutrients for the reservoir. Geraldes and Boavida 


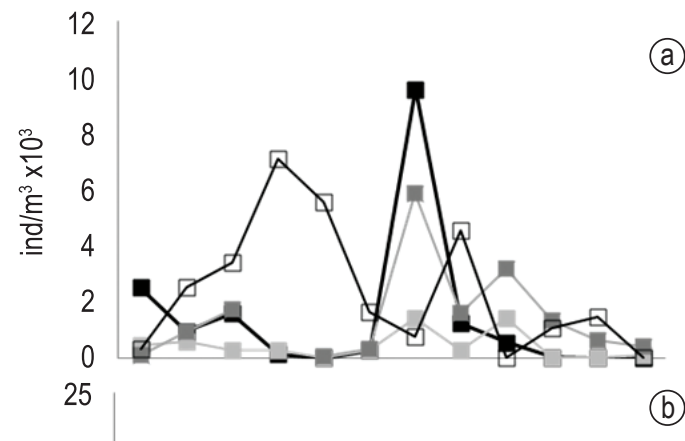

(a)

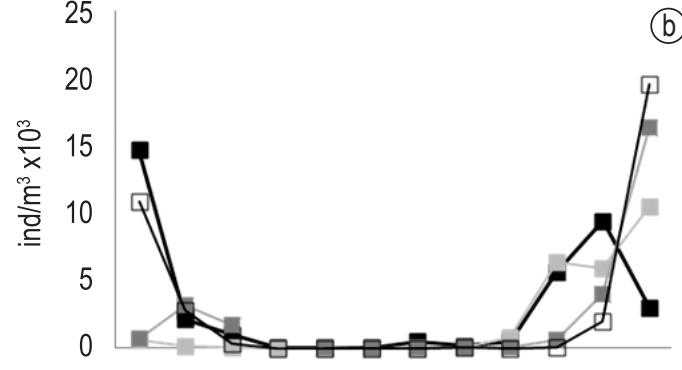

(b)
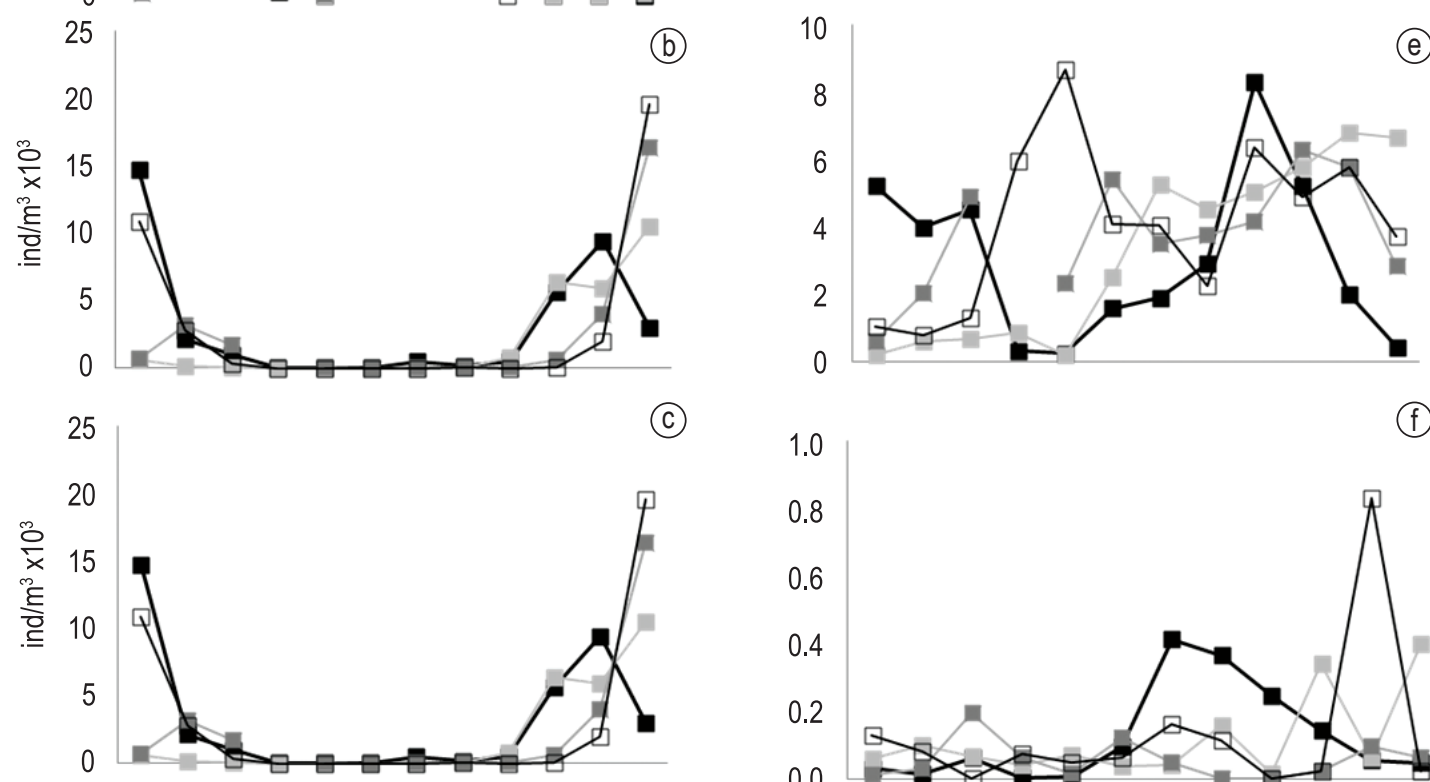

(C)

(f)

(d)
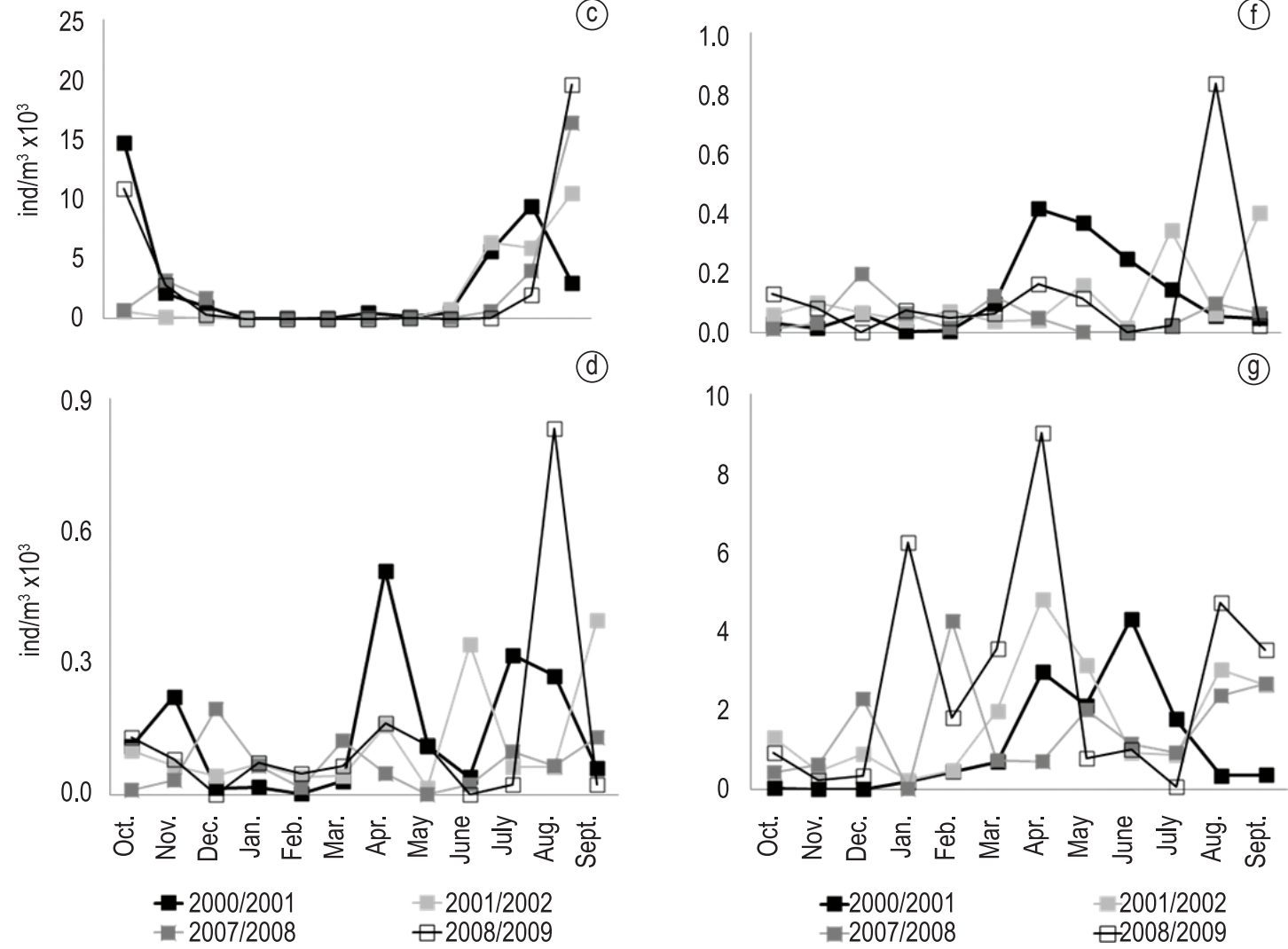

Figure 5. Seasonal and inter-annual variation of crustacean zooplankton assemblage. a) Daphnia longispina; b) Ceriodaphnia puchella; c) Diaphanosoma brachyurum; d) Bosmina longirostris; e) Copidodiaptomus. numidicus; f) Acanthocyclops robustus; g) nauplii.

(2003) noticed that in a wet year TP concentrations in this reservoir varied concomitantly with the concentrations recorded downstream of one of Azibo's tributaries.

Anabaena abundance was at least indirectly influenced by precipitation patterns. This cyanobacterium became dominant during an extensive dry period, which occurred subsequently to a very wet period (Figures 1 and 4). Vasconcelos (1990) also recorded a similar pattern for Anabaena in this reservoir. Afterwards, this species or other cyanobacteria species were undetectable on the samples collected. These organisms benefit from stable conditions coincident with high temperature and irradiance and absence of water turbulence (Reynolds et al., 2002; Barone et al., 2010). However, 


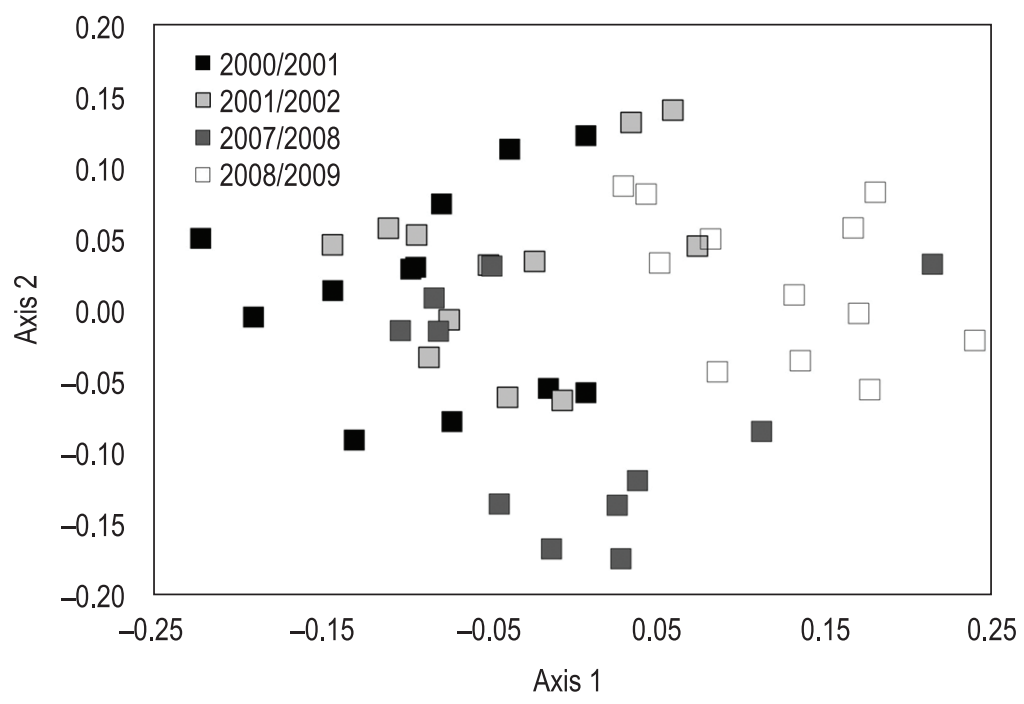

Figure 6. Canonical Analysis of Principal Coordinates of crustacean zooplankton data. Overall test for differences in dispersion among groups: Desv. centroids: F = 9.23; P = 0.00008); Pairwise comparisons: 2000/2001-2001/2002: $\mathrm{t}=3.11, \mathrm{P}=0.003 ; 2000 / 2001-2007 / 2008: \mathrm{t}=1.19, \mathrm{P}=0.247 ; 2000 / 2001-2008 / 2009: \mathrm{t}=4.07, \mathrm{P}=0.0005$; 2001/2002-2007/2008: $\mathrm{t}=2.81, \mathrm{P}=0.01 ; 2001 / 2002-2008 / 2009: \mathrm{t}=1.50, \mathrm{P}=0.10 ; 2007 / 2008-2008 / 2009$ : $\mathrm{t}=4.44, \mathrm{P}=0.0002$.

even the achievement of this ecological optimum was not enough to trigger Anabaena dominance in 2007/2008 and 2008/2009. According to Wagner and Adrian (2009), cyanobacteria, including Anabaena, are only stimulated with TP concentrations ranging from 70 to $215 \mu \mathrm{g} \mathrm{L}^{-1}$. Therefore, the optimal temperature, irradiance, TP concentrations and water turbulence combination seem to be achieved only from September to December 2001.

Annual variations reported in crustacean zooplankton assemblages were also indirectly related with rainfall variations. In 2000/2001 an atypical high precipitation from October 2000 to March 2001 induced an accentuated decline in water residence time and a considerable flushing effect could have occurred, inducing the exportation of zooplankton together with their immature instars and food sources (Rey, 1984; Godlewska et al., 2003; Romare et al., 2005). This fact could have affected the recruitment of some species. The low abundance of Daphnia, C. numidicus and nauplii observed from December 2000 to March 2001 can be explained by this hypothesis. Ceriodaphnia and Diaphanosoma were probably not affected by rainfall because they only occur during the summer months (Figure 5). Although CAP and the results of tests for homogeneity of multivariate dispersions revealed the existence of significant differences in dispersion between 2000/2001 and 2001/2002, Daphnia, C. numidicus and nauplii abundances remained low from September until December 2001, showing afterwards a different pattern from that observed in 2000/2001. While in 2000/2001 zooplankton seemed to have been directly influenced by precipitation, in 2001/2002 zooplankton might have been directly influenced by the presence of Anabaena. It is well known that cyanobacterial toxicity and mechanical interference may be important drivers in large crustacean zooplankton abundance. (e.g. Geller and Müller, 1981, Lampert and Sommer, 1997; Tillmanns et al., 2008; Sarnelle et al., 2010). Therefore, Daphnia and C. numidicus (also herbivorous) might have been strongly affected by the presence of the cyanobacterium (Figure 5). Despite of the absence of intense rainfall events in 2007/2008, Daphnia and C. numidicus populations showed an unexpected similar pattern to those observed in 2000/2001. Besides, differences in zooplankton assemblages between the two dry years (2007/2008 and 2008/2009) were also found to be significant (Figures 5 and 6). This means that annual zooplankton succession is not only related with rainfall events but depends as well on other complex interactions of several key factors. Examples could be the shifts in competitive interactions that may occur between the studied species and between those and rotifers, in edible phytoplankton assemblages (Abrantes et al., 2009) and changes in macroinvertebrate predation (Macphee et al., 2011). Temperature anomalies (Huber et al., 
2010), such as the heat waves occurred during the late summer 2009 could also have impacted zooplankton abundance and composition.

In summary, some of the observed shifts in environmental parameters (conductivity, TP concentrations and Anabaena abundance) resulting in changes in zooplankton abundance are induced by rainfall variation. The most affected species were those with a lack of seasonality (C. numidicus) or species occurring mainly in winter/early summer (Daphnia longispina). However, a wide range of physical, chemical and biotic interactions is likely to influence zooplankton abundance. Therefore, it is necessary to be cautious when relating the observed variation exclusively with rainfall intensity. In fact, some of the observed shifts might have been induced by factors varying subtly in a seasonal or interannual pattern, independently of rainfall intensity. Obtaining long data series enabling a simultaneous analysis of intra and inter-annual ecosystem changes will allow a better understanding of the complexity of interactions between climate, environmental and biological parameters. This can in turn reveal the role played by climate change and other disturbance events on reservoir limnology.

\section{Acknowledgements}

From 2000 to 2002 this study was financed by Fundação para a Ciência e a Tecnologia, Portugal (PRAXIS XXI/C/BIA/11012/98). A special thank is due to all colleagues who helped during fieldwork. The authors are grateful to one anonymous referee whose suggestions helped to improve very much an earlier version of the manuscript.

\section{References}

ABRANTES, N., NOGUEIRA, A. and GONÇALVES,

F. 2009. Short-term dynamics of cladocerans in a eutrophic shallow lake during a shift in the phytoplankton dominance. Annales de Limnologie - International Journal of Limnology, vol. 45, p. 237-245. http://dx.doi.org/10.1051/ $\operatorname{limn} / 2009027$

ALVAREZ-COBELAS, M., CIRUJANO, S., ROJO, C., RODRIGO, MA., PIÑA, E., RODRÍGUEZMURILLO, JC. and MONTERO, E. 2006. Effects of Changing Rainfall on the Limnology of a Mediterranean, Flowthrough-Seepage Chain of Lakes. International Review of Hydrobiology, vol. 91, p. 466-482. http://dx.doi.org/10.1002/ iroh.200510836

ANDERSON, MJ. and WILLIS, TJ. 2003. Canonical analysis of principal coordinates: a useful method of constrained ordination for ecology. Ecology, vol. 84, p. 511-524. http://dx.doi.org/10.1890/00129658(2003)084[0511:CAOPCA]2.0.CO;2

ANDERSON, MJ., ELLINGSEN, KE. and McARDLE, BH. 2006. Multivariate dispersion as a measure of beta diversity Ecology Letters, vol. 9, p. 683-693. PMid:16706913. http://dx.doi.org/10.1111/j.14610248.2006.00926.x

ARMENGOL, J., TOJA, J. and VIDAL, A. 1994. Seasonal rhythm and secular changes in Spanish reservoirs. In MARGALEF, R., orgs. Limnology Now: A paradigm of planetary problems. Amsterdam: Elsevier Science B.V. 572 p. PMCid:1375004.

ARMENGOL, J., GARCIA, JC., COMERMA, M., ROMERO, M., DOLZ, J., ROURA, M., HAN, BH., VIDAL, A. and ŠIMEK, K. 1999. Longitudinal processes in Canyon type reservoirs: The case of Sau (N. E. Spain). In TUNDISI, JG. and STRAŠKRABA, M., orgs. Theoretical Reservoir Ecology and its Applications. São Carlos: International Institute of Ecology, Brazilian Academy of Sciences. 585 p.

BARBOSA, AE. and HVITVED-JACOBSEN, T. 1999. Highway runoff and potential for removal of heavy metals in an infiltration pond in Portugal. Science of the Total Environment, vol. 235, p.151-159. http:// dx.doi.org/10.1016/S0048-9697(99)00208-9

BARONE, R., CASTELLI, G. and NASELLI-FLORES, L. 2010. Red sky at night cyanobacteria delight: the role of climate in structuring phytoplankton assemblage in a shallow, Mediterranean lake (Biviere di Gela, southeastern Sicily). Hydrobiologia, vol. 639, p. 43-53. http://dx.doi.org/10.1007/s10750-0090016-2

BOSTRÖM, B., PERSSON, G. and BROBERG, B. 1988. Bioavailability of different phosphorus forms in freshwater systems. Hydrobiologia, vol. 170, p. 2134. http://dx.doi.org/10.1007/BF00024902

CATALAN, J. and FEE, EJ. 1994. Interannual variability in limnic ecosystems: origin, patterns and predictability. In MARGALEF, R., orgs. Limnology Now: A paradigm of planetary problems. Amsterdam: Elsevier Science B.V. 572 p.

GELLER, W. and MÜLLER, H. 1981. The Filtration Apparatus of Cladocera: Filter Mesh-Sizes and their Implications on Food Selectivity. Oecologia, vol. 49, p. 316 -321. http://dx.doi.org/10.1007/BF00347591

GERALDES, AM. and BOAVIDA, MJ. 2003. Distinct age and landscape influence on two reservoirs under the same climate. Hydrobiologia, vol. 504, p. 277-288. http://dx.doi.org/10.1023/ B:HYDR.0000008527.21115.6c

GERALDES, AM. and BOAVIDA, MJ. 2004a. How important are emergent macrophytes to crustacean zooplankton in a meso-eutrophic reservoir? Limnetica, vol. 23, p. 57-64.

GERALDES, AM. and BOAVIDA, MJ. 2004b. What factors affect the pelagic cladocerans of the meso-eutrophic Azibo reservoir? Annales de Limnologie - International Journal of Limnology, 
vol. 40, p. 101-111. http://dx.doi.org/10.1051/ limn/2004008

GODLEWSKA, M., MAZURKIEWICZ-BORO, G., POCIECHA, A., WILK-WOZNIAK, E. and JELONEK, M. 2003. Effects of flood on the functioning of the Dobczyce reservoir ecosystem. Hydrobiologia, vol. 504, p. 305-313. http://dx.doi. org/10.1023/B:HYDR.0000008530.31142.81

HUBER, V., ADRIAN, R. and GERTEN, D. 2010. A matter of timing: Heat wave impact on crustacean zooplankton. Freshwater Biology, vol. 55, p. 1769-1779.

JEPPESEN, E., JENSEN, JP., SONDERGAARD, M. and LAURIDSEN, T. 1999. Trophic dynamics in turbid and clear water lakes with special emphasis on the role of zooplankton for water clarity. Hydrobiologia, vol. 408, p. 217-231. http://dx.doi. org/10.1023/A:1017071600486

JONES, JR., KNOWLTON, MF. and OBRECHT, DV. 2008. Role of land cover and hydrology in determining nutrients in mid-continent reservoirs: implications for nutrient criteria and management. Lake and Reservoir Management, vol. 24, p. 1-9. http://dx.doi.org/10.1080/07438140809354045

LAMPERT, W. and SOMMER, U. 1997. Limnoecology: the ecology of lakes and streams. New York: Oxford University Press. 382 p.

LEGENDRE, P. and LEGENDRE, L. 1998. Numerical Ecology. Amsterdam: Elsevier Science BV. 853 p.

MacPHEE, SA., ARNOTT, SE. and KELLER, W. 2011. Lake thermal structure influences macroinvertebrate predation on crustacean zooplankton. Journal of Plankton Research, vol. 33, p. 1586-1595. http:// dx.doi.org/10.1093/plankt/fbr046

MARCÉ, R., MORENO-OSTOS, E., ORDÓÑEZ, J., FEIJOÓ, C., NAVARRO, E., CAPUTO, L. and ARMENGOL, J., 2006. Nutrient fluxes through boundaries in the hypolimnion of Sau reservoir: expected patterns and unanticipated processes. Limnetica, vol. 25, p. 527-540.

NASELLI-FLORES, L., 2011. Mediterranean Climate and Eutrophication of Reservoirs: Limnological Skills to Improve Management. In ANSARI, AA., GILL, SS., LANZA, GR. and RAST, W., orgs. Eutrophication: causes, consequences and control. New York: Springer. 394 p.

OBERTEGGER, U., BORSATO, A. and FLAIM, G. 2010. Rotifer-crustacean interactions in a pseudokarstic lake: influence of hydrology. Aquatic Ecology, vol. 44, p. 121-130. http://dx.doi. org/10.1007/s10452-009-9285-0

PEREIRA, R., SOARES, AMVM., RIBEIRO, R. and GONÇALVES, F. 2002. Assessing the trophic state of Linhos lake: a first step towards ecological rehabilitation. Journal of Environmental Management, vol. 64, p. 285-297. http://dx.doi.org/10.1006/ jema.2001.0521

Portuguese Meteorology Institute. 2009. O clima: Boletins Climatológicos. Available from: <https://www.meteo. $\mathrm{pt} / \mathrm{pt} / \mathrm{publicacoes} /$ tecnico-cientif/noIM/boletins/ index.jsp>. (In portuguese).

REY, J. 1984. Exportation of zooplankton through an outlet in the Pyrenees. Verhandlungen des Internationalen Verein Limnologie, vol. 22, p. 1493-1497.

REYNOLDS, CS., HUSZAR, V., KRUK, C., NASELLIFLORES, L. and MELO, S. 2002. Towards a functional classification of the freshwater plankton. Journal of Plankton Research, vol. 24, p. 417-428. http://dx.doi.org/10.1093/plankt/24.5.417

ROMARE, P., SCHINDLER, DE., SCHEUERELL, MD., SCHEUERELL, JM., LITT, AH. and SHEPHERD JH. 2005. Variation in spatial and temporal gradients in zooplankton spring development: the effect of climatic factors. Freshwater Biology, vol. 50, p. 1007-1021. http://dx.doi. org/10.1111/j.1365-2427.2005.01386.x

RYBAK, J. 2000. Long-term and seasonal dynamics of nutrient export rates from lake watersheds of diversified land cover pattern. Verhandlungen des Internationalen Verein Limnologie, vol. 27, p. 3132-3136.

SARNELLE, O., GUSTAFSSON, S. and HANSSON, LA. 2010. Effects of cyanobacteria on fitness components of the herbivore Daphnia. Journal of Plankton Research, vol. 32, p. 471-477. http://dx.doi. org/10.1093/plankt/fbp151

SORIA, JM., VICENTE, E. and MIRACLE, MR. 2000. The influence of flash floods on the limnology of the Albufera of Valencia Lagoon (Spain). Verhandlungen des Internationalen Verein Limnologie, vol. 27, p. 2232-2235.

TILLMANNS, AR., WILSON, AE., PICK, FR. and SARNELLE, O. 2008. Meta-analysis of cyanobacterial effects on zooplankton population growth rate: species-specifi c responses. Archiv für Hydrobiologie, vol. 17, p. 285-295.

VASCONCELOS, VM. 1990. First approach to the limnology of Azibo Reservoir (Portugal). Publicaçóes do Instituto de Zoologia "Dr. Augusto Nobre", vol. 218, p. 1-21.

WAGNER, C. and ADRIAN, R. 2009. Cyanobacteria dominance: quantifying the effects of climate change. Limnology and Oceanography, vol. 54, p. 24602468. http://dx.doi.org/10.4319/lo.2009.54.6_ part_2.2460

WETZEL, RG. 2001. Limnology-Lake and river ecosystems. San Diego: Academic Press. 1006 p. 